\title{
Determinan Kasus Stunting pada Balita Umur 2 - 5 Tahun di Wilayah Kerja
}

\section{Puskesmas Bolo Kabupaten Bima Tahun 2019}

\author{
Nurbaety $^{1(\mathrm{CA})}$, Musmuliadin ${ }^{2}$ \\ ${ }^{1(\mathrm{CA})}$ Akademi Kebidanan Harapan Bunda Bima, Program Studi D III Kebidanan,Indonesia, \\ bettygindi@gmail.com \\ ${ }^{2}$ STIKES IST Buton, Program Studi S1 Keperawatan, mmus7199@gmail.com
}

\begin{abstract}
Stunting is a condition in which the child does not grow and develop according to their age, namely the child's height is low. Aiming to determine the determinants of stunting cases in children aged 2-5 years, this study is a quantitative analytic study with a case control method supported by qualitative analysis. Data collection was carried out from September to November 2019. There were 90 respondents in the case group (stunting) and 180 respondents in the control group (not stunting) who were taken by simple random sampling. Data analysis used chi square test and simple ligistic regression test. The results showed a significant relationship between nutritional status during pregnancy (p-value 0.009), history of exclusive breastfeeding (p-value 0.002), anemia during pregnancy (p-value 0.009), birth weight (p-value 0.000) and length of pregnancy. birth body (p-value 0.001) with cases of stunting in children aged 2-5 years. Multivariate analysis showed that there were 3 variables with p-value $<0.05$, namely nutritional status at pregnancy (0.077), history of exclusive breastfeeding (0.003), and birth weight (0.016). The variable that most affected stunting was the variable birth weight with an OR of 4.135, meaning that toddlers at birth had a birth weight $<2500$ grams and had four times the chance of becoming stunting. Researchers recommend outreach, counseling and education in each village through a deeper approach using more effective media as an effort to prevent and overcome the problem of stunting.
\end{abstract}

Keywords: Stunting, Toddler.

\begin{abstract}
ABSTRAK
Stunting merupakan keadaan dimana anak tidak tumbuh dan berkembang sesuai umurnya yakni tinggi badan anak rendah. Bertujuan untuk mengetahui determinan kasus stunting pada balita umur $2-5$ tahun, penelitian ini bersifat analitik kuantitatif dengan metode case control yang didukung analisis kualitatif. Pengumpulan data dilaksanakan pada September sampai dengan November 2019. Responden pada kelompok kasus (stunting) sebanyak 90 dan pada kelompok kontrol (tidak stunting) sebanyak 180 yang diambli secara simple random sampling. Analisis data menggunakan uji chi square dan uji regresi ligistik sederhana. Hasil penelitian menunjukkan adanya hubungan yang berarti antara status gizi waktu hamil ( $p$ value 0,009), Riwayat ASI Eksklusif ( $p$-value 0,002), Anemia waktu hamil ( $p$-value 0,009), Berat badan lahir ( $p$-value 0,000) dan Panjang badan lahir ( $p$-value 0,001) dengan kasus stunting pada balita umur 2 - 5 tahun. Analisis multivariate menunjukkan ada 3 variabel dengan $p$-value $<0,05$ yaitu Status gizi waktu hamil (0,077), Riwayat ASI Eksklusif (0,003), dan Berat badan lahir (0,016). Variabel yang paling besar mempengaruhi kasus stunting adalah variabel Berat badan lahir dengan OR 4,135 artinya Balita waktu lahir memiliki Berat badan lahir < 2500 gram mempunyai 4 kali peluang menjadi stunting. Peneliti merekomendasikan Penyuluhan, Konseling dan Edukasi di setiap desa melalui pendekatan yang lebih mendalam dengan menggunakan media yang lebih efektif sebagai upaya pencegahan dan penanggulangan masalah stunting.
\end{abstract}

Kata Kunci: Stunting, Balita. 


\section{PENDAHULUAN}

Stunting merupakan salah satu keadaan dimana anak dibawah lima tahun mengalami kegagalan tumbuh yakni tinggi badan anak rendah tidak sesuai dengan umur karena kekurangan gizi. anak yang mengalami stunting adalah anak dengan tinggi badan menurut umur (TB/U) kurang dari minus dua standar deviasi (<-2 SD) (TNPK, 2017). Diperikirakan terdapat 162 juta balita stunting pada tahun 2012, jika kasus stunting berlanjut tanpa upaya penurunan diproyeksikan meningkat menjadi 127 juta kasus stunting pada tahun 2025 (WHO, 2014).

Indonesia merupakan negara dengan jumlah kasus stunting terbanyak ke lima tingkat dunia. Kasus stunting di Indonesia lebih tinggi dari negara yang ada di Asia Tenggara yaitu Myanmar sebanyak 35\%, Vietnam sebanyak 23\%, dan Thailand sebanyak 16\%. Kasus stunting di Indonesia dari tahun 2007 sampai tahun 2013 cenderung adanya peningkatan, tahun 2007 sebesar 36,8\%, tahun 2010 sebesar 35,6\% dan tahun 2013 adalah 37,2\% (Kemenkes RI, 2013).

Salah satu provinsi yang ada di Indonesia dengan kategori serius yaitu Nusa tenggara barat dengan kasus Stunting sebanyak 65,8\% (Kemenkes RI, 2013). Kabupaten Bima merupakan kabupaten yang paling timur di provinsi NTBterdiri dari 21 Puskesmas yang terbagi dalam 18 kecamatan. Kasus balita yang mengalami Stunting hampir ditemukan disemua puskesmas di Kabupaten Bima. Puskesmas Bolo merupakan puskesmas terbanyak kedua yang melaporkan kasus Stunting sebelumnya Puskesmas Woha sebanyak 657 Kasus. Puskesmas Bolo terdiri dari 14 desa dengan kasus Stunting sebanyak 566 kasus yang tercatat sampai dengan Maret 2018 (Dinkes Kab. Bima, 2018). Secara Fasilisitas yang disediakan di Puskesmas sudah tersedia dan program penimbangan di posyandu dilaksanakan setiap tahunnya namum belum mampu menyelesaikan masalah Stunting pada balita umur 2 - 5 tahun di Kecamatan Bolo WIlayah Kerja Puskesmas Bolo.

Atas pertimbangan sumber data diatas, maka perlu adanya perhatian yang khusus dalam menangani permasalahan gizi yang ada di Indonesia. Tingginya angka rata-rata kasus stunting di Indonesia khususnya di Kecamatan Bolo, menjadi perhatian khusus dalam melakukan tindakan perbaikan gizi (stunting) sehingga dapat membantu mengurangi angka stunting. Upaya yang harus dilakukan yakni menjalankan program yang telah dibuat pemerintah. Bekerja sama dengan berbagai sektor terkait untuk menggerakan program-program tersebut, mengikutsertakan masyarakat dalam upaya tersebut mengingat dampak yang disebabkan oleh stunting itu sangat serius bagi generasi bangsa kedepannya. Upaya tersebut sesuai dengan tujuan dari Sustainable Development Goals (SDGs) yang tercantum pada tujuan ke-2 yaitu peningkatan terhadap gizi (Kemenkes RI, 2015).

Melihat tingginya kasus balita yang mengalami stunting yang terjadi di kecamatan Bolo, maka menarik perhatian peneliti untuk melihat lebih dalam lagi tentan determinan kasus stunting pada balita umur 2 - 5 tahun di Kecamatan Bolo Wilayah Kerja Puskesmas Bolo Puskesmas Bolo Kabupaten Bima Nusa Tenggara Barat Tahun 2019.

\section{METODOLOGI PENELITIAN}

\section{Penelitian Kuantitatif}

Penelitian ini yang bersifat analisis, dimana dalam penelitian dilengkapi penelitian kualitatif. 
Penelitian menggunakan case control bersifat retrospektif ialah suatu penelitian untuk menyelidiki orangorang yang terpapar (kasus) yang hendak diselidiki penyebabnya (faktor resiko) dibandingkan dengan orang-rang yang tidak terpapar tersebut (kontrol) dengan mengambil atau menanyakan keadaan atau riwayat sebelumnya yang sudah terjadi (Budiman, 2013). Dalam penelitian ini, dibagi menjadi dua kelompok meliputi kelompok kasus adalah stunting pada balita umur 2 - 5 tahun dan kelompok kontrol adalah tidak stunting pada balita umur 2 - 5 tahun.

\section{Penelitian Kualitatif}

Metode kualitatif digunakan untuk melengkapi hasil dari penelitian kuantitatif. Metode ini digunakan untuk memperoleh informasi yang lebih mendalam mengenai faktor yang berkorelasi dengan kasus stunting pada balita umur 2 - 5 tahun di Kecamatan Bolo Wilayah Kerja Puskesmas Bolo Puskesmas Bolo Kabupaten Bima Nusa Tenggara Barat tahun 2019.

\section{HASIL}

Tabel 1 Distribusi Frekuensi Status gizi waktu hamil (LILA) di Wilayah Kerja Puskesmas Bolo Kabupaten Bima Nusa Tenggara Barat Tahun 2019

\begin{tabular}{lcccc}
\hline & & \multicolumn{3}{c}{ Status Stunting } \\
Status gizi waktu hamil (LILA) & Stunting & \multicolumn{2}{c}{ Tidak Stunting } \\
& $\mathrm{n}$ & $\%$ & $\mathrm{n}$ & $\%$ \\
\hline KEK $(<23,5 \mathrm{~cm})$ & 38 & 42,2 & 41 & 22,8 \\
Tidak KEK $(\geq 23,5 \mathrm{~cm})$ & 52 & 57,8 & 139 & 77,2 \\
Total & 90 & 100 & 180 & 100 \\
\hline
\end{tabular}

Berdasarkan tabel 1 di atas dari 90 kelompok kasus dapat diketahui Status gizi waktu hamil (LILA) bahwa sebagian besar ibu Tidak KEK ( $\geq 23,5 \mathrm{~cm}$ ) sebanyak 78,9\%, sedangkan dari 180 pada kelompok kontrol sebagian besar ibu tidak KEK $(\geq 23,5 \mathrm{~cm})$ sebanyak $91,1 \%$.

Tabel 2 Distribusi Riwayat ASI Ekslusif di Wilayah Kerja Puskesmas Bolo Kabupaten Bima Nusa Tenggara Barat Tahun 2019

\begin{tabular}{lcccc}
\hline \multirow{2}{*}{ Riwayat ASI Eksklusif } & \multicolumn{3}{c}{ Status Stunting } \\
& & Stunting & \multicolumn{2}{c}{ Tidak Stunting } \\
\hline Tidak ASI Eksklusif (<0-6 Bulan) & 38 & 42,2 & 41 & $\%$ \\
ASI Eksklusif (0-6 bulan) & 52 & 57,8 & 139 & 77,2 \\
Total & 90 & 100 & 180 & 100 \\
\hline
\end{tabular}

Berdasarkan tabel 2 di atas dari 90 kelompok kasus dapat diketahui Riwayat ASI Ekslusif bahwa sebagian besar mendapatkan ASI Ekslusif (0-6 bulan) sebanyak 57,8 \% sedangkan dari 180 Kelompok Kontrol sebagian besar mendapatkan ASI Ekslusif (0-6 bulan) sebanyak 77,2\%. 
Tabel 3 Distribusi Frekuensi Anemia waktu hamil di Wilayah Kerja Puskesmas Bolo Kabupaten Bima Nusa Tenggara Barat Tahun 2019

\begin{tabular}{lcccc}
\hline & \multicolumn{3}{c}{ Status Stunting } \\
Anemia waktu hamil & & Stunting & \multicolumn{2}{c}{ Tidak Stunting } \\
& $\mathrm{n}$ & $\%$ & $\mathrm{n}$ & $\%$ \\
\hline Anemia $(<11 \mathrm{~g} / \mathrm{dl})$ & 61 & 67,8 & 98 & 54,4 \\
ASI Eksklusif $(\geq 11 \mathrm{~g} / \mathrm{dl})$ & 29 & 32,2 & 82 & 45,6 \\
Total & 90 & 100 & 180 & 100 \\
\hline
\end{tabular}

Berdasarkan tabel 3 di atas dari 90 kelompok kasus dapat di ketahui bahwa sebagian besar ibu mengalami anemia (HB < $11 \mathrm{~g} / \mathrm{dl}$ ) sebanyak 67,8\%, sedangkan pada kelompok kontrol sebagian besar ibu mengalami anemia (HB < $11 \mathrm{~g} / \mathrm{dl})$ sebanyak 54,4\%.

Tabel 4 Distribusi Frekuensi Berat badan lahir (BBL) di Wilayah Kerja Puskesmas Bolo Kabupaten Bima Nusa Tenggara Barat Tahun 2019

\begin{tabular}{|c|c|c|c|c|}
\hline \multirow{3}{*}{ Berat badan lahir } & \multicolumn{4}{|c|}{ Status Stunting } \\
\hline & \multicolumn{2}{|c|}{ Stunting } & \multicolumn{2}{|c|}{ Tidak Stunting } \\
\hline & $\mathrm{n}$ & $\%$ & $\mathrm{n}$ & $\%$ \\
\hline BBLR (<2500 gram) & 61 & 67,8 & 98 & 54,4 \\
\hline Normal ( $\geq 2500$ gram) & 29 & 32,2 & 82 & 45,6 \\
\hline Total & 90 & 100 & 180 & 100 \\
\hline
\end{tabular}

Berdasarkan tabel 4 di atas dari 90 kelompok kasus dapat diketahui bahwa berat badan lahir sebagian besar normal sebanyak 57,8 \% sedangkan dari 180 pada Kelompok Kontrol bahwa berat badan lahir sebagian besar Normal juga sebanyak $77,2 \%$.

Tabel 5 Distribusi Frekuensi Panjang badan lahir (PBL) di Wilayah Kerja Puskesmas Bolo Kabupaten Bima Nusa Tenggara Barat Tahun 2019

\begin{tabular}{|c|c|c|c|c|}
\hline \multirow{3}{*}{ Panjang badan lahir (PBL) } & \multicolumn{4}{|c|}{ Status Stunting } \\
\hline & \multicolumn{2}{|c|}{ Stunting } & \multicolumn{2}{|c|}{ Tidak Stunting } \\
\hline & $\mathrm{n}$ & $\%$ & $\mathrm{n}$ & $\%$ \\
\hline Pendek (<48 cm) & 26 & 28,9 & 21 & 11,7 \\
\hline Panjang ( $\geq 48 \mathrm{~cm})$ & 64 & 71,1 & 159 & 88,3 \\
\hline Total & 90 & 100 & 180 & 100 \\
\hline
\end{tabular}

Berdasarkan tabel 5 di atas dari 90 kelompok kasus dapat diketahui bahwa Panjang badan lahir sebagian besar Panjang sebanyak 71,1 \% sedangkandari 180 pada Kelompok Kontrol bahwa Panjang badan lahir sebagian besar juga Panjang sebanyak 88,3\%. 
Tabel 6 Distribusi Frekuensi Penyakit Infeksi Diare/ Ispa di Wilayah Kerja Puskesmas Bolo Kabupaten Bima Nusa Tenggara Barat Tahun 2019

\begin{tabular}{lcccc}
\hline & \multicolumn{3}{c}{ Status Stunting } \\
Penyakit Infeksi Diare/Ispa & \multicolumn{2}{c}{ Stunting } & \multicolumn{2}{c}{ Tidak Stunting } \\
& $\mathrm{n}$ & $\%$ & $\mathrm{n}$ & $\%$ \\
\hline Ya & 34 & 37,8 & 58 & 32,2 \\
Tidak & 56 & 62,2 & 122 & 67,8 \\
Total & 90 & 100 & 180 & 100 \\
\hline
\end{tabular}

Berdasarkan tabel 6 di atas dari 90 kelompok kasus dapat diketahui bahwa sebagian besar Balita dengan tidak mengalami Penyakit Infeksi Diare/ Ispa, sebanyak 62,2 \% sedangkan dari 180 pada Kelompok Kontrol sebagian besar Balita tidak mengalami Penyakit Infeksi Diare/ Ispa, sebanyak 67,8\%.

Tabel 7 Distribusi Frekuensi Tinggi Badan Ibu di Wilayah Kerja Puskesmas Bolo Kabupaten Bima Nusa Tenggara Barat Tahun 2019

\begin{tabular}{lcccc}
\hline \multirow{2}{*}{ Tinggi Badan Ibu } & \multicolumn{3}{c}{ Status Stunting } \\
& \multicolumn{2}{c}{ Stunting } & \multicolumn{2}{c}{ Tidak Stunting } \\
& $\mathrm{n}$ & $\%$ & $\mathrm{n}$ & $\%$ \\
\hline Pendek $(<150 \mathrm{~cm})$ & 54 & 60,0 & 112 & 62,2 \\
Tidak $(\geq 150 \mathrm{~cm})$ & 36 & 40,0 & 68 & 37,8 \\
Total & 90 & 100 & 180 & 100 \\
\hline
\end{tabular}

Berdasarkan tabel 7 di atas dari 90 kelompok kasus dapat diketahui bahwa tinggi badan ibu sebagian besar Pendek $(<150 \mathrm{~cm})$ sebanyak 60,0 \% sedangkan dari 180 pada Kelompok Kontrol bahwa tinggi badan ibu sebagian besar juga Pendek $(<150 \mathrm{~cm})$ sebanyak 62,2\%.

Tabel 8 Hubungan Status gizi waktu hamil (LILA) dengan kasus Stunting di Wilayah Kerja Puskesmas Bolo Kabupaten Bima Nusa Tenggara Barat Tahun 2019

\begin{tabular}{lcccccccc}
\hline \multicolumn{1}{c}{ Status Gizi Ibu } & \multicolumn{4}{c}{ Status Stunting } & & & $P$ Value & OR \\
Hamil (LILA) & \multicolumn{2}{c}{ Stunting } & \multicolumn{2}{c}{ Tidak Stunting } & \multicolumn{2}{c}{ Total } & & $(95 \%$ CI $)$ \\
& $\mathrm{n}$ & $\%$ & $\mathrm{n}$ & $\%$ & $\mathrm{n}$ & $\%$ & & \\
\hline KEK & 19 & 21,1 & 16 & 8,9 & 35 & 13,0 & 0,009 & 2,743 \\
Tidak KEK & 71 & 78,9 & 164 & 91,1 & 235 & 87,0 & & $(1,334-5,641)$ \\
Total & 90 & 100 & 180 & 100 & 270 & 100,0 & & \\
\hline
\end{tabular}

Pada tabel 8 menunjukan hasil analisis hubungan Status gizi waktu hamil (LILA) dengan kasus Stunting diperoleh p-value $0,009<(0,05)$ maka Ho ditolak dapat disimpulkan ada hubungan yang signifikan antara Status gizi waktu hamil (LILA) dengan kasus Stunting. Dengan OR 2,743 (1,334-5,641) 
artinya ibu dengan Status gizi Waktu hamil (LILA) $($ KEK $<23,5 \mathrm{~cm})$ berisiko 3 kali untuk memiliki Balita Stunting dibandingkan dengan ibu dengan Status gizi Waktu hamil (LILA) (Tidak KEK $\geq 23,5 \mathrm{~cm}$ ).

Tabel 9 Hubungan Riwayat ASI Eksklusif dengan kasus Stunting di Wilayah Kerja Puskesmas Bolo Kabupaten Bima Nusa Tenggara Barat Tahun 2019

\begin{tabular}{|c|c|c|c|c|c|c|c|c|}
\hline \multirow{3}{*}{$\begin{array}{c}\text { Riwayat ASI } \\
\text { Eksklusif }\end{array}$} & \multicolumn{4}{|c|}{ Status Stunting } & & & \multirow[t]{3}{*}{$P$ Value } & \multirow{3}{*}{$\begin{array}{c}\text { OR } \\
(95 \% \mathrm{CI})\end{array}$} \\
\hline & \multicolumn{2}{|c|}{ Stunting } & \multicolumn{2}{|c|}{ Tidak Stunting } & \multicolumn{2}{|c|}{ Total } & & \\
\hline & $\mathrm{n}$ & $\%$ & $\mathrm{n}$ & $\%$ & $\mathrm{n}$ & $\%$ & & \\
\hline Tidak ASI & 38 & 42,2 & 41 & 22,8 & 79 & 29,3 & 0,002 & 2,477 \\
\hline Eksklusif & & & & & & & & $(1,438-4,270)$ \\
\hline ASI Eksklusif & 52 & 57,8 & 139 & 77,2 & 191 & 70,7 & & \\
\hline Total & 90 & 100 & 180 & 100 & 270 & 100,0 & & \\
\hline
\end{tabular}

Pada tabel 9 menunjukan bahwa hubungan Riwayat ASI Eksklusif dengan kasus Stunting diperoleh $p$-value $0,002<(0,05)$ maka Ho ditolak dapat disimpulkan ada hubungan yang signifikan antara Riwayat ASI Eksklusif dengan kasus Stunting. Kemudian dari hasil analisis diperoleh OR 2,477 (1,4384.270) artinya Balita yang memiliki Tidak ASI Eksklusif < 6 bulan berisiko 2 kali untuk terjadi Stunting dibandingkan dengan Balita yang memiliki ASI Eksklusif $\geq 6$ bulan.

Tabel 10 Hubungan Anemia waktu hamil dengan kasus Stunting di Wilayah Kerja Puskesmas Bolo Kabupaten Bima Nusa Tenggara Barat Tahun 2019

\begin{tabular}{lcccccccc}
\hline Anemia waktu hamil & \multicolumn{4}{c}{ Status Stunting } & & & $P$ Value & OR \\
& & Stunting & \multicolumn{2}{c}{ Tidak Stunting } & \multicolumn{2}{c}{ Total } & & $(95 \%$ CI $)$ \\
& $\mathrm{n}$ & $\%$ & $\mathrm{n}$ & $\%$ & $\mathrm{n}$ & $\%$ & & \\
\hline Anemia $(<11 \mathrm{~g} / \mathrm{dl})$ & 61 & 67,8 & 98 & 54,4 & 159 & 58,9 & 0,049 & 1,760 \\
Tidak Anemia & 28 & 32,2 & 82 & 45,6 & 111 & 41,1 & & $(1,035-2,992)$ \\
$(\geq 100 \mathrm{~g} / \mathrm{dl})$ & & & & & & & \\
Total & 90 & 100 & 180 & 100 & 270 & 100,0 & & \\
\hline
\end{tabular}

Pada tabel 10 menunjukan bahwa hubungan anemia waktu hamil dengan kasus stunting diperoleh p-value $0,049<(0,05)$ maka Ho ditolak dapat disimpulkan ada hubungan yang signifikan antara Anemia waktu hamil dengan kasus Stunting. Dengan OR 1,760 (1,035-2.992) artinya ibu yang mengalami Anemia waktu hamil berisiko 2 kali untuk mengalami Stunting dibandingkan dengan ibu yang tidak Anemia waktu hamil.

Pada tabel 11 berikut menunjukan bahwa hubungan berat badan lahir (BBL) dengan kasus stunting diperoleh $p$-value $0,000<(0,05)$ maka Ho ditolak dapat disimpulkan ada hubungan yang signifikan antara Berat badan lahir (BBL) dengan kasus Stunting. Kemudian dari hasil analisis diperoleh OR 7,250 (2,76519.009) artinya Balita yang memiliki berat badan lahir (BBLR $<2500$ gram) berisiko 7 kali terjadinya 
stunting dibandingkan dengan balita yang berat badan lahir (normal $\geq 2500$ gram).

Tabel 11. Hubungan Berat badan lahir (BBL) dengan kasus Stunting di Wilayah Kerja Puskesmas Bolo Kabupaten Bima Nusa Tenggara Barat Tahun 2019

\begin{tabular}{lcccccccc}
\hline \multirow{1}{*}{$\begin{array}{c}\text { Berat badan lahir } \\
\text { (BBL) }\end{array}$} & \multicolumn{9}{c}{ Status Stunting } & & & P Value & OR \\
& Stunting & \multicolumn{2}{c}{ Tidak Stunting } & \multicolumn{2}{c}{ Total } & & $(95 \% \mathrm{CI})$ \\
& $\mathrm{n}$ & $\%$ & $\mathrm{n}$ & $\%$ & $\mathrm{n}$ & $\%$ & & \\
\hline BBLR & 38 & 42,2 & 41 & 22,8 & 24 & 8,9 & 0,000 & 7,250 \\
Normal & 52 & 57,8 & 139 & 77,2 & 246 & 91,1 & & $(2,756-$ \\
Total & 90 & 100 & 180 & 100 & 270 & 100,0 & & $19,009)$ \\
\hline
\end{tabular}

Tabel 12 Hubungan Panjang badan lahir (PBL) dengan kasus Stunting di Wilayah Kerja Puskesmas Bolo Kabupaten Bima Nusa Tenggara Barat Tahun 2019

\begin{tabular}{lcccccccc}
\hline \begin{tabular}{l} 
Panjang badan lahir \\
\multicolumn{1}{c}{ (PBL) }
\end{tabular} & \multicolumn{9}{c}{ Status Stunting } & & & P Value & OR \\
& $\mathrm{n}$ & $\%$ & $\mathrm{n}$ & $\%$ & $\mathrm{n}$ & $\%$ & & $(95 \% \mathrm{CI})$ \\
& 26 & 28,9 & 21 & 11,7 & 47 & 17,4 & 0,001 & 3,076 \\
\hline Pendek & 64 & 71,1 & 159 & 88,3 & 223 & 82,6 & & $(1,615-5,857)$ \\
Panjang & 90 & 100 & 180 & 100 & 270 & 100,0 & & \\
Total & & & & & & & &
\end{tabular}

Pada tabel 12 menunjukan bahwa hubungan panjang badan lahir (PBL) dengan kasus stunting diperoleh $p$-value $0,001<(0,05)$ maka Ho ditolak dapat disimpulkan ada hubungan yang signifikan antara panjang badan lahir (PBL) dengan kasus Stunting. Dengan OR 3,076 (1,615-5.857) artinya Balita yang memiliki panjang badan lahir (Pendek $<48 \mathrm{~cm}$ ) berisiko 3 kali terjadinya stunting dibandingkan dengan Balita yang memiliki Panjang badan lahir (Panjang $\geq 48 \mathrm{~cm}$ ).

Tabel 13 Hubungan Riwayat Penyakit Infeksi (Diare/Ispa) dengan kasus Stunting di Wilayah Kerja Puskesmas Bolo Kabupaten Bima Nusa Tenggara Barat Tahun 2019

\begin{tabular}{lcccccccc}
\hline \multicolumn{1}{c}{$\begin{array}{c}\text { Riwayat penyakit } \\
\text { infeksi (Diare/Ispa) }\end{array}$} & \multicolumn{9}{c}{ Stunting } & \multicolumn{2}{c}{ Tidak Stunting } & \multicolumn{2}{c}{ Total } & & OR Value & (95\% CI) \\
& $\mathrm{n}$ & $\%$ & $\mathrm{n}$ & $\%$ & $\mathrm{n}$ & $\%$ & & \\
\hline Ya & 34 & 37,8 & 58 & 32,2 & 92 & 34,1 & 0,440 & 1,277 \\
Tidak & 56 & 62,2 & 122 & 67,8 & 178 & 65,9 & & $(0,753-2,166)$ \\
Total & 90 & 100 & 180 & 100 & 270 & 100,0 & & \\
\hline
\end{tabular}

Pada tabel 13 menunjukan hasil analisis hubungan Riwayat Penyakit Infeksi (Diare/Ispa) dengan kasus Stunting diperoleh $p$-value 0,440 > $(0,05)$ maka Ho gagal ditolak dapat disimpulkan tidak ada hubungan yang signifikan antara Riwayat Penyakit Infeksi (Diare/Ispa) dengan kasus Stunting. 
Tabel 14 Hubungan Tinggi Badan Ibu dengan kasus Stunting di Wilayah Kerja Puskesmas Bolo Kabupaten Bima Nusa Tenggara Barat Tahun 2019

\begin{tabular}{lcccccccc}
\hline Tinggi Badan Ibu & \multicolumn{4}{c}{ Status Stunting } & & & $P$ Value & OR \\
& \multicolumn{2}{c}{ Stunting } & \multicolumn{2}{c}{ Tidak Stunting } & \multicolumn{2}{c}{ Total } & & $(95 \%$ CI $)$ \\
& $\mathrm{n}$ & $\%$ & $\mathrm{n}$ & $\%$ & $\mathrm{n}$ & $\%$ & & \\
\hline Pendek & 54 & 60,0 & 112 & 62,2 & 166 & 61,5 & 0,825 & 0,911 \\
Normal & 36 & 40,0 & 68 & 37,8 & 104 & 38,5 & & $(0,542-1,529)$ \\
Total & 90 & 100 & 180 & 100 & 270 & 100,0 & & \\
\hline
\end{tabular}

Pada tabel 14 menunjukan hasil analisis hubungan tinggi badan ibu dengan kasus Stunting diperoleh nilai p-value $0,825<(0,05)$ maka Ho gagal ditolak dapat disimpulkan tidak ada hubungan yang signifikan antara tinggi badan ibu dengan kasus Stunting.

Tabel 15 Analisis Multivariat

\begin{tabular}{lccccc}
\hline \multicolumn{1}{c}{ Variabel } & B & P & $\mathbf{E x p ( B )}$ & $\begin{array}{r}\mathbf{9 5 , 0 \%} \text { C.I.for EXP(B) } \\
\text { Lower }\end{array}$ & Upper \\
\hline Status gizi waktu hamil (LILA) & & & & 0,925 & 4,568 \\
Riwayat ASI Eksklusif & 0,721 & 0,077 & 2,056 & 0,925 \\
Berat badan lahir (BBL) & 0,859 & 0,003 & 2,361 & 1,329 & 4.193 \\
Anemia waktu hamil & 1,419 & 0,016 & 4,135 & 1,298 & 13,172 \\
Panjang badan lahir (PBL) & 0,290 & 0,329 & 1,336 & 0,747 & 2,390 \\
\multicolumn{1}{c}{ Constant } & 0,344 & 0,416 & 1,410 & 0,616 & 3,226 \\
\hline
\end{tabular}

Berdasarkan tabel 15 di dapatkan model akhir analisis multivariat. ada 3 variabel yang bermakna dengan kasus Stunting adalah Status gizi waktu hamil (LILA), Riwayat ASI Eksklusif, dan Berat badan lahir. OR yang paling signifikan adalah Berat badan lahir yaitu 4,135 artinya balita yang lahir dengan berat badan lahir rendah (<2500 gram) mempunyai peluang 4 kali untuk mengalami Stunting.

Koefisien determinan(Negelkerke $R$ Square) menunjukkan nilai 0,163 maksudnya adalah model regresi yang didapatkan menjelaskan 16,3\% variasi variabel terikat. Status gizi waktu hamil (LILA), Riwayat ASI Eksklusif dan Berat badan lahir menjelaskan variasi variabel determinan stunting pada balita umur 2 - 5 tahun di Kecamatan Bolo Wilayah Kerja Puskesmas Bolo Kabupaten Bima NTB tahun 2019 yakni sebesar $16,3 \%$ sisanya $83,7 \%$ dapat dijelaskan dari variabel lain..

Probabilitas balita mengalamiStunting sebesar 57\%, Dengan demikian Peluang untuk terjadinya stunting pada balita umur 2 - 5 tahun yang memiliki Status gizi waktu hamil (LILA) $<23,5 \mathrm{~cm}$, Riwayat ASI Ekslusif (< 6 Bulan) dan Berat badan lahir (<2500 gram) sebesar 57\%. 


\section{PEMBAHASAN}

Berdasarkan analisis uji regresi logistik didapatkan hasil bahwa variabel yang dominan yang berkorelasi dengan kasus stunting padabalita umur 2 - 5 tahun di Kecamatan Bolo Wilayah Kerja Puskesmas Bolo Puskesmas Bolo Kabupaten Bima Nusa Tenggara Barat tahun 2019 adalah variabel status gizi Waktu Hamil, Riwayat ASI Eksklusif dan Berat badan lahir. Variabel yang paling dominan mempengaruhi stunting yakni variabel Berat badan lahir dengan nilai Exp (B) 4,135 yang artinya Berat badan lahir (BBLR <2500 gram) memiliki 4 kali kesempatan terhadap risiko terjadinya stunting.

Penelitian ini sejalan dengan penelitian yang dilakukan oleh Atikah Rahayu (2015) di Wilayah Puskesmas Sungai Karias, Hulu Sungai Utara. menunjukan ada hubungan yang signifikan antara riwayat Berat badan lahir rendah dengan kasus Stunting dengan p-value 0,015. Hasil penelitian ini menunjukan ada pengaruh riwayat BBLR dengan kasus stunting dengan nilai OR 5,876 artinya anak yang mempunyai riwayat BBLR berisiko sebesar 5,9 kali menjadi balita Stunting. Penelitian lain dilakukan oleh Darwin Nasution (2013) menunjukan ada hubungan yangbermakna riwayat BBLR dengan Kasus stunting dengan p-value sebesar 0,000. Hasil analisis menunjukkan nilai OR=5,60 (95\% CI: 2,27-15,70), artinya pada tingkat kepercayaan 95\% dapat disimpulkan bahwa anak yang lahir dengan BBLR mempunyai risiko 5,6 kali lebih besar untuk menjadi stunting dibandingkan dengan anak yang lahir dengan berat badan normal.

Berat badan lahir adalah berat badan bayi ketika lahir atau paling lambat sampai bayi berumur 1 hari dilihat dari KMS (Kartu Menuju Sehat) dimana bila Berat badan lahir kurang dari 2500 gram berarti Berat badan lahir rendah dan bila lebih dari atau sama dengan 2500 gram berarti normal. Berat badan lahir rendah banyak dihubungkan dengan tinggi badan yang kurang atau stunting pada balita (Maulidah et al., 2019).

Berdasarkan hasil wawancara bahwa kejadian bayi lahir dengan BBLR atau Berat badan lahir kurang dari 2500 gram masih sangat banyak ditemukan di Puskesmas Bolo dan sebagian ibu mengatakan kalau berat badan waktu lahir kurang dari 2500 gram. Berdasarkan dari hasil wawancara yaitu ibu balita mengatakan bahwa ukuran LILA sewaktu hamil tidak normal dan informan tenaga kesehatanpun mengatakan bahwa hasil pemeriksaan ANC ibu-ibu banyak yang mengalami KEK dan itu terlihat dari ukuran LILAnya kurang dari $23 \mathrm{~cm}$ dan masalah lainnya banyak ibu yang mengalami kurang gizi karena selama hamil ibu memilih makanan yang disukai dan tidak membuat mual dan muntah seperti bakso dan mie tanpa memperhatikan gizi yang sesuai kebutuhan selama hamil. (hasil studi kualitatif).

Searah dengan hasil penelitian Loida dkk. bahwa berat badan lahir itu mempengaruhi kejadian stunting pada Usia 24-59 Bulan (Loida, 2017). Hasil penelitian lain yang searah yakni penelitian Atikah Rahayu (2015), diperoleh bahwa faktor yang paling dominan mempengaruhi kejadian stunting di Wilayah Puskesmas Suangai Karias, Hulu Sungai Utara adalah BBLR (Rahayu et al., 2019). Menurut Soekirman dan United Nations Children's Emergency Fund (UNICEF) bahwa asupan gizi dan penyakit infeksi yang ganas sangat mempengaruhi secara langsung terhadap status gizi dari baik menjadi rendah. Jika hal tersebut tidak ditangani dengan serius, maka keadaan ini akan terus berlanjut sampai anak tumbuh dewasa (UNICEF, 2013).

Dengan demikian menurut pendapat peneliti bahwa berat badan bayi bermula dari dalam 
kandungan. Ibu hamil yang kurang asupan nutrisi akan berisiko melahirkan bayi dengan berat badan kurang dari 2500 gram (BBLR) yang mana hal tersebut berpotensi terjadinya stunting. Ibu hamil yang pemenuhan asupan gizi kurang, Dengan mendapatkan asupan nutrisi yang baik dan optimal maka status gizi kurang dapat dicegah dari awal sehingga anak yang dilahirkan tidak lahir dengan BBLR dengan harapan kasus stunting pada balita juga ikut menurun.

Kasus stunting memiliki efek buruk terhadap tumbuh kembang anak, kecerdasan anak akan terhambat, anak akan rentan terhadap berbagai penyakit baik menular maupun tidak menular, pada usia dewasa mengalami penurunan produktivitas, menghambat laju pertumbuhan perkembangan ekonomi, produktivitas pasar kerja akan menurunkan dan mengakibatkan hilangnya 11\% GDP serta terjadinya pengurangan pendapatan pekerja dewasa berdampak langsung pada keluarga dan lebih jauh pada pembangunan bangsa (Hestuningtyas \& Noer, 2014).

Oleh karena itu bidan dan dibantu oleh kader lebih meningkatkan edukasi tentang gizi selama kehamilan kepada masyarakat terutama ibu hamil dan WUS yang berkunjung ke Puskesmas bolo untuk dapat mengetahui dan mempersiapkan gizi sebelum kehamilan, untuk mencegah ibu hamil mengalami KEK (Kurang Energi Kronis), untuk mencegah ibu melahirkan bayi dengan BBLR dan memotivasi dan mengajak masyarakat terutama ibu yang melahirkan bayi dengan berat badan lahir kurang untuk mengikuti posyandu sehingga dapat memantau pertumbuhan dan perkembangan anaknya serta mengetahui kebutuhan gizi selama tumbuh kembang agar tidak terjadi stunting (Wulandari \& Kusumastuti, 2020).

\section{KESIMPULAN}

Variabel yang berkorelasi dengan kasus stunting padabalita umur 2 - 5 tahun di Wilayah Kerja Puskesmas Bolo Kabupaten Bima Nusa Tenggara Barat tahun 2019 adalah variabel status gizi waktu hamil, Riwayat ASI Eksklusif dan Berat badan lahir. Variabel yang paling dominan mempengaruhi stunting yakni variabel Berat badan lahir dengan nilai Exp (B) 4,135 yang artinya Berat badan lahir (BBLR <2500 gram) memiliki 4 kali kesempatan terhadap risiko terjadinya stunting. Peneliti merekomendasikan Penyuluhan, Konseling dan Edukasi di setiap desa melalui pendekatan yang lebih mendalam dengan menggunakan media yang lebih efektif sebagai upaya pencegahan dan penanggulangan masalah stunting.

\section{DAFTAR PUSTAKA}

Budiman, A. (2013). Kapita Selekta Instrumen: Pengetahuan dan Sikap dalam Penelitian Kesehatan. Salemba Medika.

Hestuningtyas, T. R., \& Noer, E. R. (2014). Pengaruh konseling gizi terhadap pengetahuan, sikap, praktik ibu dalam pemberian makan anak, dan asupan zat gizi anak stunting usia 1-2 tahun di Kecamatan Semarang Timur. Journal of Nutrition College, 3(1), 17-25.

Kemenkes RI. (2013). Riset Kesehatan Dasar 2013. Badan Penelitian dan Pengembangan Kesehatan.

Kemenkes RI. (2015). Kesehatan dalam kerangka Sistainable Development Goals (SDG'S.

Loida. (2017). Factors Associated with Stunting among Children Aged 0 to59 Months from the Central Region of Mozambique. Nutrients, 9, 491. 
Maulidah, W. B., Rohmawati, N., \& Sulistiyani, S. (2019). Faktor yang berkorelasi dengan kasus stunting pada balita di Desa Panduman Kecamatan Jelbuk Kabupaten Jember. Ilmu Gizi Indonesia, 2(2), 89100.

Rahayu, A., Rahmi, P., Anggraini, L., \& Rahman, M. A. (2019). Potensi Petani Ikan Dalam Modifikasi Menu Gizi Keluarga Untuk Mencegah Kasus stunting Pada Balita Dengan Pendekatan Ftad (Farmers Team Achievement Division. Jurnal Abdimas Kesehatan (JAK), 1(3), 157-64.

TNPK. (2017). 100 Kabupaten/Kota Prioritas untuk intervensi anak kerdil (Stunting. http://www.tnp2k.go.id/images/uploads/downloads/Binder_Volume1.pdf.

UNICEF. (2013). Improving child nutrition: the achievable imperative for global progress. UNICEF.

WHO. (2014). WHA global nutrition targets 2025: Stunting policy brief. https://www.who.int/nutrition/publications/globaltargets2025_policybrief_stunting/en/.

Wulandari, H. W., \& Kusumastuti, I. (2020). Pengaruh Peran Bidan, Peran Kader, Dukungan Keluarga dan Motivasi Ibu terhadap Perilaku Ibu dalam Pencegahan Stunting pada Balitanya. Jurnal Ilmiah Kesehatan, 19(02), 73-80. 